\title{
TRICHINOSIS IN ALDERSHOT
}

Major D. E. BRADFORD, M.B., Ch.B., M.R.C.P.E., D.T.M.\&H.; R.A.M.C.

Cambridge Military Hospital, Aldershot

Colonel P. J. RICHARDS, D.S.O., O.B.E., M.R.C.S., L.R.C.P., Late R.A.M.C. (Retd.) Mons Officer Cadet School, Aldershot

Colonel T. G. A. L. WARRINGTON, M.D., M.R.C.Path., D.T.M.\&H., Late R.A.M.C. Leishman Laboratory, Aldershot

Colonel J. F. WEBB, M.C., M.D., M.R.C.P., Late R.A.M.C.

Cambridge Military Hospital, Aldershot

SUMMARY. An outbreak of trichinosis involving 26 soldiers occurred in Aldershot in November 1969, and is described. The incidence of major symptoms and signs was lower than in other described infections and may have been due to the high standard of fitness of the patients.

Serum enzyme studies were found helpful as an index of muscle involvement during the disease.

\section{Introduction}

A platoon of Guardsmen, stationed in Aldershot, were on exercise on Dartmoor from 31 October 1969 to 5 November 1969. On the last day of the exercise a number felt unwell with muscle pains but attributed this to the recent activity. The following day, off duty in Aldershot, 12 reported sick with various symptoms which included puffiness of the eyes, sore throat and generalised aches and pains. Three soldiers were sufficiently ill to be admitted to hospital where a high eosinophil count in the peripheral blood suggested trichinosis as the possible diagnosis.

A total of 40 soldiers were thought to be at risk. Twenty-six showed a significant eosinophilia (over $450 / \mathrm{cu} \mathrm{mm}$ ) but of these only 23 had symptoms. Further investigations on these 26 soldiers, which included serological studies, serum amino-transferase and serum creatine phosphokinase (C.P.K.) levels, trichinella latex tests, estimation of antibody to blood group $\mathrm{P}$ substances, electrocardiograms and muscle biopsy, were subsequently performed and the details are shown in Table I.

\section{Source of Infection}

It is thought likely that infestation occurred during a training exercise in South Wales on the 9th October 1969. On that day the troops had left their base camp early in the morning for a full day's training. They returned late at night and under pressure from hungry soldiers the cook served under-done pork.

\section{The symptoms}

The features described in the County Kerry outbreak (Corridan and Gray, 1969) were used as our yardstick in assessment and Table II compares the incidence of symptoms noted by them with our own series. Table III shows the incidence of some,common features compared with other outbreaks. 
Details of 26 soldiers infected with Trichinelia Spiralis

\begin{tabular}{|c|c|c|c|c|c|c|c|c|c|c|}
\hline \multirow[t]{2}{*}{ Case } & \multirow[t]{2}{*}{$\begin{array}{c}\text { Age } \\
\text { (years) }\end{array}$} & \multirow[t]{2}{*}{$\begin{array}{l}\text { Duration of } \\
\text { illness } \\
\text { (days) }\end{array}$} & \multirow{2}{*}{$\begin{array}{c}\text { Maximum } \\
\text { Eosinophilia } \\
\text { (cells/cu mm) }\end{array}$} & \multirow{2}{*}{$\begin{array}{c}\text { Trichinella } \\
\text { latex } \\
\text { test }\end{array}$} & \multirow{2}{*}{$\begin{array}{c}\text { Complement } \\
\text { fixation } \\
\text { test }\end{array}$} & \multicolumn{2}{|c|}{$\begin{array}{l}\text { Amino-transferase } \\
\text { Karmen units per cent }\end{array}$} & \multicolumn{2}{|c|}{ 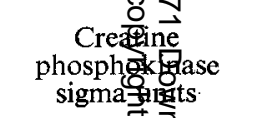 } & \multirow[t]{2}{*}{ Muscle biopsy } \\
\hline & & & & & & S.G.O.T. & S.G.P.T. & 45 days & days & \\
\hline 1. & 21 & 7 & 5,700 & - & + & 30 & 35 & 22 & 으 6 & + \\
\hline 2 & 22 & 0 & 1,090 & - & - & 30 & 10 & 16 & $\overrightarrow{\bar{\sigma}} 15$ & - \\
\hline 3 & 23 & 3 & 1,080 & + & + & 20 & 10 & 6 & 䒜 27 & Not done \\
\hline 4 & 22 & 4 & 3,920 & - & + & 17 & 10 & 9.5 & 36.5 & - \\
\hline 5 & 20 & 7 & 1,800 & - & - & 20 & 27 & 16.5 & 害 18 & - \\
\hline 6 & 21 & 2 & 2,640 & 一 & - & 35 & 45 & 35 & $\underset{D}{\grave{D}} 11$ & - \\
\hline 7 & 20 & 2 & 1,510 & - & - & 15 & 7.5 & 12 & $\stackrel{0}{\stackrel{0}{J}} 20$ & Not done \\
\hline 8 & 25 & 4 & 2,190 & 一 & - & 30 & 25 & 26 & $\underline{5} 18$ & - \\
\hline 9 & 21 & 3 & 5,560 & 一 & + & 85 & 50 & 130 & 을 8 & + \\
\hline 10 & 20 & 1 & 2,320 & - & - & 43 & 15 & 47 & 으 18 & - \\
\hline 11 & 18 & 2 & 1,590 & - & + & -15 & 7.5 & 14 & $\frac{7}{0} 28$ & - \\
\hline 12 & 19 & 3 & 1,700 & - & - & 35 & 20 & 20 & $\underset{N}{N} 7$ & 一 \\
\hline & & & & & & & & & $\begin{array}{l}\text { N } \\
\text { N } \\
\text { W } \\
\text { O } \\
\stackrel{0}{0} \\
\stackrel{0}{\mathbb{D}} \\
\stackrel{?}{+}\end{array}$ & \\
\hline
\end{tabular}




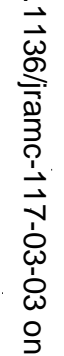

\begin{tabular}{|c|c|c|c|c|c|c|c|c|c|c|}
\hline 13 & 24 & 7 & 5,940 & - & + & 43 & 45 & 9.5 & 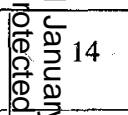 & $\begin{array}{l}\text { Eosinophilic Myositis } \\
\text { Negative needle biopsy }\end{array}$ \\
\hline 14 & 21 & 0 & 2,070 & - & + & 30 & 40 & 9.5 & $\frac{1}{0} 7$ & - \\
\hline 15 & 22 & 5 & 3,200 & + & + & 30 & 30 & 30 & $8 \div 26$ & - \\
\hline 16 & 18 & 1 & 1,000 & - &.+ & 15 & 20 & 6 & 응- & - \\
\hline 17 & 21 & 3 & 1,580 & - & - & 135 & 68 & 200 & 55 & - \\
\hline 18 & 20 & 7 & 3,460 & - & + & 20 & 15 & 7 & $\frac{\circ}{D} 13$ & - \\
\hline 19 & 21 & 14 & 7,850 & - & + & 50 & 40 & 61 & $\overrightarrow{\frac{2}{\overrightarrow{0}}}^{27}$ & $\begin{array}{l}\text { Eosinophilic Myositis } \\
\text { Negative needle biopsy }\end{array}$ \\
\hline 20 & 21 & 7 & 3,400 & - & + & 35 & 60 & 5.5 & 蔦 9.5 & $\begin{array}{l}\text { Eosinophilic Myositis } \\
\text { Needle biopsy not done }\end{array}$ \\
\hline 21 & 22 & 0 & 1,600 & - & - & 17 & 10 & 0 & 5 & - \\
\hline 22 & 20 & 2 & 3,960 & - & + & 70 & 55 & 108 & $\sum_{=}^{2} 15$ & - \\
\hline 23 & 20 & 2 & 1,700 & - & Not done & & Not esti & mated & 离 & + \\
\hline 24 & 19 & 5 & 4,760 & - & + & 25 & 20 & 25 & 16 & - \\
\hline 25 & 21 & 7 & 2,310 & - & - & 17 & 5 & 5.5 & ìn- & - \\
\hline 26 & 21 & 3 & 1,100 & - & - & 15 & 12.5 & 7 & 34 & - \\
\hline . & & 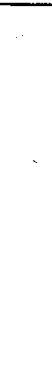 & 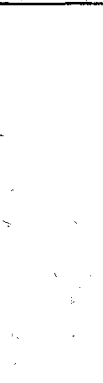 & , & . & . & & & 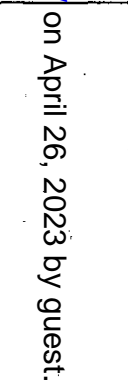 & . \\
\hline
\end{tabular}


Table II

Comparison of symptoms Kerry (1968) and Aldershot (1969)

\begin{tabular}{|c|c|c|c|c|c|}
\hline Symptoms & $\begin{array}{c}\text { Kerry } \\
\text { (50 cases) } \\
\text { per cent }\end{array}$ & $\begin{array}{l}\text { Aldershot } \\
\text { (26 cases) } \\
\text { per cent }\end{array}$ & & $\begin{array}{c}\text { Kerry } \\
\text { (50 cases) } \\
\text { per cent }\end{array}$ & $\begin{array}{c}\text { Aldershot } \\
\text { (26 cases) } \\
\text { per cent }\end{array}$ \\
\hline $\begin{array}{l}\text { Swelling of the eye } \\
\text { Tiredness } \\
\text { Headache } \\
\text { Pains all over } \\
\text { Fever } \\
\text { Loss of appetite } \\
\text { Sweating } \\
\text { Pains in legs } \\
\text { Pains in arms } \\
\text { Thirst } \\
\text { Dizziness } \\
\text { Difficulty in looking } \\
\text { at lights } \\
\text { Sore throat }\end{array}$ & $\begin{array}{l}92 \\
74 \\
70 \\
68 \\
66 \\
66 \\
66 \\
64 \\
64 \\
64 \\
42 \\
\\
40 \\
36\end{array}$ & $\begin{array}{r}48 \\
76 \\
68 \\
36 \\
60 \\
36 \\
28 \\
32 \\
40 \\
24 \\
40 \\
\\
8 \\
52\end{array}$ & $\begin{array}{l}\text { Difficulty in sleeping } \\
\text { Cough } \\
\text { Vomiting } \\
\text { Diarrhoea } \\
\text { Swelling of legs } \\
\text { Pains in joints } \\
\text { Unable to walk } \\
\text { Rash } \\
\text { Constipation } \\
\text { Loss of memory } \\
\text { Improved appetite } \\
\text { Sense of impending } \\
\text { death } \\
\text { Paralysis }\end{array}$ & $\begin{array}{r}34 \\
32 \\
30 \\
26 \\
20 \\
18 \\
16 \\
14 \\
12 \\
6 \\
\\
8\end{array}$ & $\begin{array}{r}16 \\
\frac{28}{20} \\
\frac{8}{8} \\
12 \\
8 \\
8 \\
4 \\
16 \\
8 \\
-\end{array}$ \\
\hline
\end{tabular}

Table III

Comparison of equivalent features in Trichinosis outbreaks in Liverpool (Semple et al, 1954), Glamorgan (Evans and Lennox, 1953), Kerry (Corridan and Gray, 1969) and Aldershot

\begin{tabular}{|c|c|c|c|c|}
\hline Features & $\begin{array}{c}1953 \\
\text { Liverpool } \\
\text { (82 cases) } \\
\text { per cent }\end{array}$ & $\begin{array}{c}1953 \\
\text { Glamorgan } \\
\text { (25 cases) } \\
\text { per cent }\end{array}$ & $\begin{array}{c}1968 \\
\text { Kerry } \\
\text { (50 cases) } \\
\text { per cent }\end{array}$ & $\begin{array}{c}1969 \\
\text { Aldershot } \\
\text { (26 cases) } \\
\text { per cent }\end{array}$ \\
\hline $\begin{array}{l}\text { Orbital oedema } \\
\text { Muscle pains } \\
\text { Headache } \\
\text { Fever } \\
\text { Vomiting } \\
\text { Diarrhoea } \\
\text { Eosinophilia }\end{array}$ & $\begin{array}{c}100 \\
94 \\
88 \\
\frac{30}{8} \\
--\frac{-1,-}{\text { cu mm }} \\
550-1,200\end{array}$ & $\begin{array}{c}100 \\
96 \\
40 \\
44 \\
12 \\
16 \\
-0 \\
\text { cumm } \\
1,000-7,000\end{array}$ & $\begin{array}{c}92 \\
68 \\
70 \\
66 \\
30 \\
26 \\
-\ldots-\ldots\end{array}$ & $\begin{array}{c}48 \\
36 \\
68 \\
60 \\
\overline{20} \\
------ \\
\text { cu mm } \\
500-8,000\end{array}$ \\
\hline
\end{tabular}

Trichinella latex test

\section{Investigations}

We were able to obtain sufficient material for 26 tests of which only 2 per positive.

Serology tests

Complement fixation tests were done on sera on 23 November 1969 (forty-five days after infection) and produced 14 positives (56 per cent). These results were later confirmed by the Bentonite flocculation test.

\section{Serum enzyme studies}

Serum creatine phosphokinase was measured by a method developed by the Sigma Chemical Company (Sigma, 1967). Levels of amino-transferases Serum glutamic oxaloacetic transaminase (S.G.O.T.) and Serum glutamic pyruvic transaminase (S.G.P.T.) of over 40 Karmen units per cent and levels of C.P.K. over 20 sigma units were regarded 
as abnormal. Eight soldiers (32 per cent) showed a raised level of serum amino-transferase while a raised C.P.K. was found in 12 (48 per cent).

\section{Blood group antigen}

Blood group antibody against $\mathrm{P}$. substance was sought in the serum of the patient, taken at 71 days, without success.

\section{Muscle biopsy}

Twenty-six muscle biopsies were performed in all. Open biopsy was done on 3 patients on the fortieth day following infection and all 3 specimens showed an eosinophilic myositis.

Three months after the illness a further 23 muscle biopsy specimens were obtained, each from the right deltoid muscle, using a modified Vim-Silverman biopsy needle. Three of these showed the characteristic larvae.

\section{Electrocardiograms}

Electrocardiograms were done on 23 patients at the time of needle biopsy and all were normal.

\section{Discussion}

We were fortunate in this outbreak to obtain such a clear history of raw pork consumption prior to symptoms, but even so we were unable to trace the actual source of the infected pork. This has been the experience of others (Semple, Davies, Kershaw and Hill, 1954) and emphasises the difficulty in maintaining accurate records whenever pigs or pig products change hands.

Comparison with previously described infections demonstrated a lower incidence of symptoms such as muscle pains and swelling of the eyes in our patients and this we attributed to their general state of fitness.

We were unable to emulate the success of Corridan and Gray (1969) with the Trichinella latex test and shortage of test material prevented repeat investigation.

Our results showed the value of serological tests in the diagnosis of the disease, but during the acute stage we found serum enzyme studies most useful.

Elevation of serum glutamic oxaloacetic and pyruvic amino-transferases occur in the second to the fourth week of the illness (Maynard and Kagan, 1963), but estimation of these levels in our cases was not as helpful as assessment of the serum C.P.K. Malik, Niewiarouske and Rachon (1962) showed that serum aldolase rose in the early weeks of the disease while Doege et al (1969) found that 4 out of 5 of their patients had significantly raised levels of C.P.K. A significant level of over 20 sigma units in 48 per cent confirms this a very useful test during the early stages, although in assessment of C.P.K. levels it must be remembered that different methods give different normal values.

Because of an increase in blood group antibodies, and in particular of anti $\mathrm{P}$, in some parasitic infections (Pardoe, 1970) the sera of our cases were tested for anti P but all were negative.

Eosinophilic infiltration was seen in all 3 of the open muscle biopsies taken but. digestion and wet preparation made from the biopsies failed to demonstrate any larvae. 
Open biopsy, allowing a larger piece of muscle to be taken, affords a greater chance of identifying the parasite, but needle biopsy has the advantage of minimum of inconvenience to the patient. The technique using a modified Vim-Silverman needle is simple and the biopsies were done as an out-patient procedure. Because of the smallness of the specimen, serial sections were cut to examine as much muscle as possible and our three positive biopsies were found after viewing about 1,200 sections. Electrocardiograms recorded late in the disease were normal.

\section{Acknowledgements}

We are indebted to Colonel J. H. Bennett (Retd.), then D.A.D.A.H. Southern Command for investigation of the source of the outbreak, to Dr. D. Denham of the London School of Hygiene and Tropical Medicine for the complement fixation tests, to Dr. I. G. Kagan of the National Communicable Disease Centre, Atlanta for the Bentonite flocculation tests, to the staff of the Army Blood Supply Depot for the anti P estimations, to Hyland Laboratories, Thetford for the prompt supply of trichinella latex material and to the staff of the Leishman Laboratory, Aldershot who processed the numerous investigations.

\section{REFERENCES}

Corridan, J. P. and Gray, J. J. (1969). Brit. med. J. ii, 727.

Doege, T. C., Thienprasit, P., Headington, J. T., Pongrrot, B. and Tarawanich, S. (1969), Lancet i, 459.

Evans, A. D. and Lennox, M. (1953). Brit. med. J. ii, 131.

Malik, A., Niewiarowske, S. and Rachon, K. (1962). Proceedings of the First International Conference in Trichinellosis, Warsaw. p. 219.

Maynard, J. E. and Kagan, I. G. (1963). Practitioner 191, 622.

Pardoe, G. I. (1970). Brit. J. Hosp. Med. 3, 393.

Semple, A. B., Davies, J. B. M., Kershaw, W. E. and Hill, C. A. S. (1954). Brit. med. J. i, 1002.

Sigma (1967). Sigma Technical Bulletin No. 661, May 1967. Sigma Chemical Company, St. Louis. 